\title{
Circulating Endothelial Cell Count
}

National Cancer Institute

\section{Source}

National Cancer Institute. Circulating Endothelial Cell Count. NCI Thesaurus. Code C96592.

The determination of the amount of circulating endothelial cells present in a sample. 